Agro-Science Journal of Tropical Agriculture, Food, Environment and Extension Volume 19 Number 2 (Apr. 2020) pp. 53 - 58

ISSN 1119-7455

\title{
DIFFERENTIALS IN MARKET COMPETITIVENESS AMONG SWEET POTATO FARMERS IN SOUTH EAST, NIGERIA: A GENDER ANALYSIS
}

\author{
${ }^{* 1,2}$ Okoye A.C., ${ }^{2}$ Mbanasor J.A., ${ }^{3}$ Okoye F.U. and ${ }^{1}$ Saad A.S. \\ ${ }^{1}$ National Root Crops Research Institute Umudike, PMB 7006 Umuahia, Abia State, Nigeria \\ ${ }^{2}$ Michael Okpara University of Agriculture, Umudike, Abia State, Nigeria \\ ${ }^{3}$ Federal College of Agriculture, Ishiagu, Ebonyi State, Nigeria \\ *Corresponding author's email: okoyeamalac@yahoo.com
}

\begin{abstract}
Sweet potato has emerged as an attractive crop of choice for resource-constrained households in Nigeria as it promotes food security and economic growth. Nigeria is the third largest producer of sweet potato in the world, yet the level of market competitiveness in and outside the country remains poor. This study provided empirical data on gender analyses of market competitiveness among sweet potato farmers in Nigeria. A total of 360 farmers were sampled using a multi-stage procedure and data analyzed using Policy Analysis Matrix. The result showed that sweet potato production had positive private and social prices for male and female farmers indicating that the system was competitive at given prevalent government policies and transfers and utilized scarce resources efficiently. The result also shows a negative social and private policy divergence for male and female farmers indicating that the net effect of policy intervention reduced profitability at the farm level which is detrimental to producers. The coefficients of competitiveness and comparative advantage indicators shows that nominal protection coefficient on tradable outputs and on tradable inputs, effective protection coefficient, domestic resource cost ratio, social cost benefit ratio and private cost ratio were less than unity for both male and female farmers indicating competitiveness in sweet potato production in the study area. If Nigeria is going to attain self-sufficiency in the production of sweet potato and effectively compete in the market with other countries, there is an urgent need on removal of policy distortions through increased incentives and more reduction in the cost of labour through sweet potato mechanization.
\end{abstract}

Key words: competitive advantage, farm budget and policy analysis matrix (PAM)

\section{INTRODUCTION}

Global changes in market liberalization, rapid population growth and urbanization have a direct impact on farmer, thereby making farming more competitive than before. These trends impact on farmers who need to develop stronger marketing opportunities, competencies and diversification strategies to cope with the ever-changing farming environment (Kahan, 2013). Latruffe (2010) viewed competitiveness as the ability to sell products that meet demand requirements (price, quality, quantity) while enhancing profits over time for the farm to thrive. It is the ability to face competition and be successful in the face of competition. Competition may be within domestic or international markets, depending on whether farmers or sectors are compared within or across countries.

The study conducted by FAO (2013) revealed that the input and marketing system become more complex and sophisticated as countries become more market-driven in response to the opening up to local, regional and international markets. Its potentials in competition are also expected to increase thus, there is need for farmers to adapt to changing global conditions and also do profitably (Kahan, 2013). Farm produce sold at the market must be of sufficient quantity and quality for it to be able to compete with similar products from other places according to FAO (2013).

In developing economies, sweet potato is a unique food security crop (Adubasim et al., 2017). Nigeria is the second highest producer of sweet potato in Africa with annual output of 3.46 million metric tonnes, and the third largest producer in the world, after China and Tanzania (FAOSTAT, 2017). FAO (2013) noted that production of sweet potato in Nigeria increased from 1.49 million metric tonnes in 1961 to 3.46 million metric tonnes in 2013. Area of cultivation increased from 13,000 ha to 111,500 ha while yield decreased from 11 to 3.049 t/ha over the same period (Figure 1). However, according to FAOSTAT data, globally, Nigeria is not among the major sweet potato export countries.

The growing demand for sweet potato in Nigeria has an advantage for competition as farmers exploit the local market since most of the Nigerian 180 million people depend on smallholder farmers to be fed thereby creating great opportunity for increased 
market competitiveness. Market competition allow farmers and other marginalized groups especially women to realize their competitiveness in agricultural production activities (Timmer, 2005) and exchange marketable surplus for purchasing products and services that cannot be produced at home. Farmers by the increased commercialization of sweet potato face gender-related constraints which put women at a distinct disadvantage relative to men especially in marketability.

Studies show how structural and socio-cultural barriers to women's access to productive resource, markets and market information impinge on their efficiency, creating a "gender gap" (FAO, 2001; Quisumbing, 2003; Hill and Vigneri, 2011; Quisumbing et al., 2014; David, 2015). Farmers with small farm holdings are often affected by such, fluctuations in the prices of inputs and output especially sweet potato farmers. These farmers who are market specified are also being influenced by competition from other farmers within and outside the country. To achieve competitiveness among sweet potato farmers, this study is necessary as market competitiveness commands competition among the producers making them to move towards market-oriented farming and also encourages rural agrarian households to move into productive agriculture rather than moving out of agriculture, thereby contributing to agricultural and rural development (Mazumdar, 1987) and broadbased structural transformation (ADB, 2013).

\section{MATERIALS AND METHODS}

The study was carried out in Nigeria with reference to South East geo-ecological zone. Data were collected from both primary and secondary sources. A stratified sampling design was used for the study. The design adopted five stages multi method that involves purposive, random and systematic procedures to select sample respondents. Three out of the five states (Anambra, Enugu and Ebonyi) in the South East zone were purposively selected based on the sweet potato production intensity. Two agricultural zones per state and two local government areas (LGA) per zone were randomly selected each giving 12 LGAs. In the fourth stage, three communities were selected randomly from each LGA giving a sample of 36 communities. In the last stage, 10 (5 males and 5 females) sweet potato producers were systematically selected, giving a total of 360 respondents for the study.

Structured questionnaire coupled with focal group discussion and oral interview were used for data collection. The instruments were structured to collect data on producer's production expenditure, sales, and revenue for. World reference and subsidized prices of sweet potato roots were used as reference prices for computing social prices for output and input respectively were sourced as secondary data from FAOSTAT.

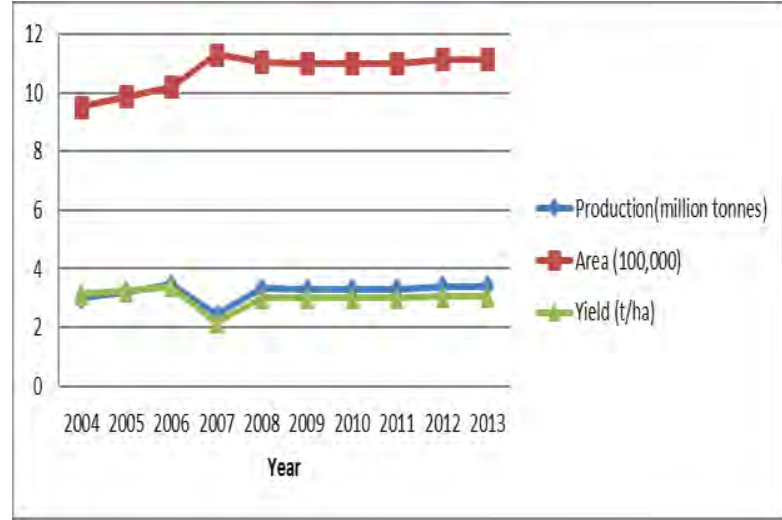

Figure 1: Trend in sweet potato production, area and yield in Nigeria: 2004-2013 (FAO, 2013)

The level of competitiveness among the sweet potato farmers was estimated using the Policy Analysis Matrix (PAM) (Table 1), following Monke and Pearson (1989) and Pearson et al. (2003). The PAM constructed made use of farm budget values (sales revenue and input cost) obtained from the field (primary data) as private price and prices from FAO data as social price (secondary data for the year 2016). The world prices were adjusted for cost of transportation to be comparable with farm gate price. The social price of land is the opportunity cost of land as net return (profit) of the competing crop production system. Following Ogbe et al. (2011), the social valuation of labour was calculated by:

$$
\mathrm{PL}=\mathrm{Wp}+0.5 \mathrm{Wo} / 2
$$

where PL is social price of labour; Wp is prevailing wage rate in peak season; Wo is prevailing wage rate in off peak season.

The PAM contains two cost columns; one of the columns comprises tradable inputs and the other for domestic factors (Table 1). Intermediate inputs including fertilizer, pesticides, purchased seeds, compound feeds, electricity, transportation, and fuel are divided into their tradable-input and domestic factor components. This process of disaggregation of intermediate goods or services separates intermediate costs into three categories namely tradable inputs, domestic factors, transfers (taxes or subsidies that are set aside).

Ratio indicators which are useful in asserting the level of competitiveness between production systems were calculated from the PAM framework following Monke and Pearson (1989) and Masters and Winter-Nelson (1995). Comparison of unlike outputs: private cost ratio (PCR): $\mathrm{C} /(\mathrm{A}-\mathrm{B})$. Domestic resource cost ratio (DRC): $\mathrm{G} /(\mathrm{E}-\mathrm{F})$. Nominal protection coefficient (NPC) on tradable outputs (NPCO): $\mathrm{A} / \mathrm{E}$, on tradable inputs (NPCI): $\mathrm{B} / \mathrm{F}$. Effective protection coefficient (EPC): (A $\mathrm{B}) /(\mathrm{E}-\mathrm{F})$. Profitability coefficient $(\mathrm{PC})$ : $(\mathrm{A}-\mathrm{B}-$ $\mathrm{C}) /(\mathrm{E}-\mathrm{F}-\mathrm{G})$ or $\mathrm{D} / \mathrm{H}$. Subsidy ratio to producers (SRP): L/E or $(\mathrm{D}-\mathrm{H}) / \mathrm{E}$. 
Table 1: Policy Analysis Matrix (PAM) for estimating the level of competitiveness among sweet potato farmers

\begin{tabular}{lcccc}
\hline Items & Revenues & Cost of tradable inputs & Cost of domestic factors & Profits \\
\hline Private prices & $\mathrm{A}$ & $\mathrm{B}$ & $\mathrm{C}$ & $\mathrm{D}$ \\
Social prices & $\mathrm{E}$ & $\mathrm{F}$ & $\mathrm{G}$ & $\mathrm{H}$ \\
Policy divergences & $\mathrm{I}$ & $\mathrm{J}$ & $\mathrm{K}$ & $\mathrm{L}$ \\
\hline Developed by Monke and Pearson (1989); where 1. Private profits (D) $=\mathrm{A}-\mathrm{B}-\mathrm{C}$, 2. Social profits $(\mathrm{H})=\mathrm{E}-\mathrm{F}-\mathrm{G}$ & \\
3. Output Transfer $(\mathrm{I})=\mathrm{A}-\mathrm{E}$, 4. Input Transfer $(\mathrm{J})=\mathrm{B}-\mathrm{F}$, 5. Factor Transfer $(\mathrm{K})=\mathrm{C}-\mathrm{G}$, and 6. Net transfer $(\mathrm{L})=\mathrm{D}-\mathrm{H}$ or I- J $-\mathrm{K}$
\end{tabular}

\section{RESULTS AND DISCUSSION}

Description of Sweet Potato Producers

The result in Table 2 shows the socio-economic characteristics of sweet potato producers in the South East Geo-Political Zone of Nigeria. The findings show the mean age of the male farmers (47.63) was more than their female (43.03) counterparts with a household size of about 6 persons each. This indicated that the farmers were still young, active, agile and within the productive age and with large household sizes. The results also show that both the male and female farmers attained primary education with a mean score of 6.82 and 7.74 years, respectively.

The male farmers had more years of farming experience (17.44) than their female counterparts (14.3), and marketing experience of 11.33 and 10.02years for male and female sweet potato producers respectively. The size of farm varies across gender in the study area. The total area of land cultivated for agricultural activities were 1.54 and 0.73 hectares for male and female farmers respectively while total area of land cultivated with sweet potato was 0.37 (male) and 0.46 (female) ha. This implies that all the respondents had small land holdings and grow sweet potato on a small scale, and the likely implication of this is small output. Majority of the female and male respondents were married $(90.56 \%$ and $85 \%$, respectively) and belonged to cooperative societies $(77.65 \%$ and $86.11 \%$, respectively).

\section{Level of Competitiveness of Sweet Potato Production}

In other to measure competitiveness of sweet potato production, farm budget analysis was estimated for male and female sweet potato producers.

\section{Farm Budget Analysis of Sweet Potato Production}

Table 3 shows the farm budget analysis per hectare of sweet potato in South East, Nigeria. The results show a total variable cost per hectare at private price of $\$ 219,052$ and $\$ 225,663.11$ for male and female producers respectively and social price of $¥ 188,965.21$ and $\$ 191,916.26$ for male and female producers respectively. The total fixed cost at private price for male and female farmers were $\aleph 59,200.42$ and $52,650.25$ and at social price of $¥ 44,400.11$ and $\$ 44,400.11$, respectively.

The results also show that sweet potato production is profitable with the value of 190,858.99 and $\$ 149,142.14$ at private levels and $\aleph 309,202.27$ and $¥ 262,511.86$ at social levels for
Table 2: Average characteristics of the sweet potato farmers in South East, Nigeria

\begin{tabular}{lccc}
\hline Variable Description & Male & Female & Pooled \\
No of observation & 180 & 180 & 360 \\
\hline Age & 47.63 & 43.03 & 45.41 \\
& $(9.63)$ & $(0.89)$ & $(11.05)$ \\
Household size & 5.9 & 5.81 & 5.86 \\
& $(2.20)$ & $(2.32)$ & $(2.26)$ \\
Educational level & 6.82 & 7.74 & 7.28 \\
(years) & $(5.52)$ & $(4.84)$ & $(5.19)$ \\
Farming experience & 17.44 & 14.43 & 15.97 \\
(years) & $(8.06)$ & $(8.11)$ & $(8.17)$ \\
Marketing experience & 11.33 & 10.02 & 10.69 \\
(years) & $(7.28)$ & $(7.19)$ & $(7.19)$ \\
Total area of & $1.54(0.5$ & 0.73 & 1.12 \\
land cultivated & $9)$ & $(0.46)$ & $(0.51)$ \\
Total area of land & 0.37 & 0.46 & 0.41 \\
cultivated with sweet potato & $(0.12)$ & $(0.12)$ & $(0.12)$ \\
Dummy (\%) & & & \\
Married & 85.00 & 90.56 & 87.22 \\
$\begin{array}{l}\text { Member of } \\
\text { cooperative society }\end{array}$ & 86.11 & 77.65 & 79.45 \\
\hline Source: Field Survey, 2016. Figures in & & \\
standard deviations & \multicolumn{3}{l}{} \\
& & & \\
& &
\end{tabular}

male and female producers, respectively. The budget returns of 1.69 (male) and 11.54 (female) was also estimated for every $\$ 1$ spent at private level. Also, for every $\$ 1$ spent, about $\$ 2.33$ and $\$ 2.11$ were derived at social price for male and female respectively. These indicate that the tradable and domestic resources are being efficiently utilized in the production of sweet potato.

The labour cost at social prices were lower than at private prices indicating that labour is the most important and highest variable cost item in Nigeria. This partly explains the higher profit at social prices because labour is cheaper beyond the boarder. For Nigeria to compete effectively at the international market for sweet potato, there is a need for more reduction in labour cost and this can be achieved through sweet potato mechanization

\section{Policy Analysis Matrix (PAM) for Sweet Potato Production}

The Policy Analysis Matrix (PAM) for sweet potato production in South East, Nigeria is presented in Table 4. The result shows that sweet potato production had positive private profit for males at $\$ 190,858.99$ and females at $\$ 149,142.14$ per hectare. This implied that the farmers were competitive given prevalent government policies and transfers, (i.e., given current technologies, prices of inputs and outputs, and policy) and that producers are earning supernormal returns following the study of Ogbe et al. (2011). The lower return for female farmers at private price was due to the price per unit of the product. 
Table 3: Farm budget for per hectare of sweet potato in South East, Nigeria

\begin{tabular}{|c|c|c|c|c|}
\hline \multirow{2}{*}{$\begin{array}{l}\text { Activities } \\
\text { Labour }\end{array}$} & \multicolumn{2}{|c|}{ Male } & \multicolumn{2}{|c|}{ Female } \\
\hline & Private Price $(\mathrm{N})$ & Social Price $(\mathrm{N})$ & Private Price $(\mathrm{N})$ & Social Price $(\mathrm{N})$ \\
\hline Land clearing & 14400 & 11700 & 18000 & 14625 \\
\hline Land preparation & 42000 & 34125 & 45600 & 37050 \\
\hline Vine preparation & 6000 & 4875 & 6000 & 4875 \\
\hline Planting & 13200 & 10725 & 10800 & 8775 \\
\hline Weeding & 33600 & 27300 & 38400 & 31200 \\
\hline Fertilization/manuring & 10800 & 8775 & 14400 & 11700 \\
\hline Pesticide application & 2400 & 1950 & 2400 & 1950 \\
\hline Herbicide application & 2400 & 1950 & 2400 & 1950 \\
\hline Harvesting & 36000 & 29250 & 39600 & 32175 \\
\hline Carriage and other expenses & 12000 & 9750 & 12000 & 9750 \\
\hline Total A & 172,800 & 140,400 & 189,600 & 154,050 \\
\hline \multicolumn{5}{|l|}{ B. Other inputs } \\
\hline Sweet potato vine & 21972.15 & 23070.7575 & 14729.57 & 15466.0485 \\
\hline Fertilizer & 16807.84 & 17648.232 & 15236.41 & 15998.2305 \\
\hline Herbicides & 2480.95 & 2604.9975 & 2106.94 & 2212.287 \\
\hline Pesticides & 1205.36 & 1265.628 & 1200 & 1260 \\
\hline Bags & 1435.5 & 1507.275 & 1213.09 & 1273.7445 \\
\hline Baskets & 2350.79 & 2468.3295 & 1577.1 & 1655.955 \\
\hline Total B & $46,252.59$ & $48,565.2195$ & $36,063.11$ & $37,866.27$ \\
\hline Total variable cost $A+B$ & $2190,52.59$ & $188,965.2195$ & $225,663.11$ & $191,916.27$ \\
\hline \multicolumn{5}{|l|}{ C. Fixed cost } \\
\hline Depreciation & 5569.17 & 4176.83 & 5267.77 & 4176.83 \\
\hline Interest on capital & 19270.63 & 14452.82 & 14963.05 & 14452.82 \\
\hline Land rent & 12500 & 9375 & 12500 & 9375 \\
\hline Taxes & 21860.6192 & 16395.46 & 19919.4263 & 16395.46 \\
\hline Insurance & 0 & 0 & 0 & 0 \\
\hline Total fixed cost & $59,200.42$ & $44,400.11$ & $52,650.25$ & $44,400.11$ \\
\hline Total cost & $278,253.0092$ & $233,365.3295$ & $278,313.3563$ & $236,316.3755$ \\
\hline Revenue & 469112 & 542567.6 & 427455.5 & 498828.23 \\
\hline Profit & 190858.9908 & 309202.2705 & 149142.1437 & 262511.8545 \\
\hline Revenue-Cost ratio (TR/TC) & 1.69:1 & $2.33: 1$ & $1.54: 1$ & 2.11: 1 \\
\hline
\end{tabular}

Source: Own calculations from Field Survey, 2017 and FAOSTAST, 2017

Table 4: Policy Analysis Matrix of sweet potato production system in South East, Nigeria ( $\mathrm{N} / \mathrm{ha}$ )

\begin{tabular}{llcccc}
\hline & Items & Revenues & Cost of tradable inputs & Cost of domestic factors & Profits \\
\hline Male & Private prices & 469112 & 46252.59 & 232000.42 & 184800.11 \\
& Social prices & 542567.6 & 48565.22 & 47200.31 & 309202.27 \\
& Policy divergences & -73455.6 & -2312.63 & & \\
& & & & 242250.25 & 118343.28 \\
Female & Private prices & 427455.5 & 36063.11 & 198450.11 & 262511.82 \\
& Social prices & 498828.2 & 37866.27 & 43800.14 & -113369.71 \\
& Policy divergences & -71372.7 & -1803.16 & & \\
\hline
\end{tabular}

Source: Own calculation from farm budget

The results also show a positive social profit for male and female farmers at $\$ 309,202.27$ and 262,511.82 respectively. This implies that the farmers utilized scarce resources efficiently in the production of sweet potato and that the farmer can survive without government interventions at the margin. This can further be confirmed from their PCR values in Table 5 which were less than unity following Ekunwe and Atalor (2007) that indicated a positive PC less than one for plantain processed products. However, the findings report a negative social and private policy divergence of $-\$ 118343.28$ for the male farmers and $-13,369.71$ for the female farmers. This indicates that the net effect of policy intervention reduced profitability at the farm level which is detrimental to producers. The finding disagrees with the finding of Ogbe et al. (2011) who noted a positive private profit for upland rice, irrigated rice and upland maize, and negative private profit for lowland rice and irrigated maize following Adeoye and Oni (2013).
Coefficients of Competitiveness, Protection and Comparative Advantage of Sweet Potato Production System

The results in Table 5 show coefficients of protection and comparative advantage of sweet potato producers in South East, Nigeria. The result of the analysis indicates that NPCO of 0.86 each were obtained for male and female sweet potato producers which indicates that sweet potato market price were $14 \%$ below the world reference price. This indicates that sweet potato production system was not protected by policy as a result of transfer of resources from the system and that substantial output tax applies. The Nominal Protection Coefficients on input (NPCI) such as tools and equipment used in the production of sweet potato were less than unity. This implies that the input costs in all the production systems were lower than the world reference price by $5 \%$ each for male and female producers, thus suggesting that government policies were reducing tradable inputs cost for sweet potato production in the study area. 
Table 5: Coefficients of competitiveness, protection and comparative advantage of producers in sweet potato system of South East, Nigeria

\begin{tabular}{|c|c|c|}
\hline \multirow{2}{*}{ Indicators } & \multicolumn{2}{|c|}{ Value } \\
\hline & Male & Female \\
\hline Nominal Protection & 0.8646 & 0.8569 \\
\hline Coefficient for Output (NPCO) & & \\
\hline Nominal Protection & 0.9524 & 0.9524 \\
\hline Coefficient for Input (NPCI) & & \\
\hline Effective Protection & 0.8559 & 0.8491 \\
\hline Coefficient (EPC) & & \\
\hline Private Profitability & 0.6173 & 0.5681 \\
\hline Coefficient (PPC) & & \\
\hline Domestic Resource Cost (DCR) & 0.3741 & 0.4305 \\
\hline Coefficient & & \\
\hline Social Cost Benefit Ratio (SCBR) & 0.4301 & 0.4737 \\
\hline Private Cost Ratio (PCR) & 0.5486 & 0.6189 \\
\hline Subsidy Ratio Producer (SRP) & -0.2181 & -0.2273 \\
\hline
\end{tabular}

The result also shows that Effective Protection Coefficient (EPC) was less than unity. This indicates that value sold at market prices were lower than the value sold at world reference price. It further explained that producers were not protected through policy intervention on marketing produce and face net tax of $14 \%$ and $15 \%$ for male and female producers respectively. The private profitability coefficients were also less than one with the value of 0.61 and 0.57 for male and female producers respectively. The result of the analysis of the profitability coefficient indicated that private profits were lower than profit obtained at world reference price level indicating that the polices transfer income away from the production system.

The domestic resource cost (DRC) coefficients for male $(0.37)$ and female $(0.43)$ producers were similarly less than unity, indicating that the value of domestic resources used in sweet potato production is lower than the value added. This implies an efficient use of domestic resources in sweet potato production and that production for male and female were socially profitable. Consequently, Nigeria has no comparative advantage in sweet potato production. The results indicate high value of DRC for female than their male counterparts indicating that the female producers were relatively making more profit in terms of use of domestic factor.

The social cost benefit ratio (SCBR) indicator is another competitiveness indicator, as it is more sensitive to errors and serves to determine whether production is really competitive and whether it creates net social revenue for the country. Thus, SCBR for sweet potato production is 0.43 and 0.47 for male and female farmers, respectively. This implies that sweet potato production in South East Nigeria is competitive. In other words, their expense on 1 tonne of produced sweet potato is $43 \%$ and $47 \%$ of revenue for male and female producers, respectively. This also confirmed the DRC value obtained on efficiency in the use of domestic factors for both farmers.
To estimate the competitiveness of sweet potato production and show how much the farmers can afford to pay domestic factors (including a normal return to capital) and still remain competitive that is break even after normal profits (Monke and Pearson, 1989), the private cost ratio (PCR) was estimated. The results show the PCR value of 0.55 and 0.62 for male and female producers respectively. This implies that sweet potato production is competitive at the current level of technology and policy intervention. However, the male production system appeared to be more competitive than their female counterparts.

Subsidy ratio to producer (SRP) values of -0.22 and -0.23 were obtained for male and female sweet potato producers, respectively. Monke and Pearson (1989) noted that SRP shows the level of transfers from divergences as a proportion of undistorted value of the system revenue. Hence, if market failures are not an important component of the divergence, then SRP shows the extent to which a system's revenue have been increased or decreased because of policy. A negative SRP indicate that the producers were taxed in the production of the commodity. The equivalent producer subsidy estimate for male and female producers were also less than unity, indicating implicit tax and transfer of resources from the system. This implies that $78 \%$ and $77 \%$ for male and female producers, respectively of the divergences are used to subsidize other commodities. This suggests that there is a decrease in gross revenue of the system and hence further confirms that the production of sweet potato was taxed by policy.

\section{CONCLUSION}

The study showed that there exist gender differences in the market competitiveness of male and female smallholder sweet potato farmers in Nigeria. However, the PAM finding indicated that both male and female production systems were competitive thus, the male sweet potato production system appeared to be more competitive than their female counterparts. The study therefore calls for the need on the removal of policy distortions to increase the incentive for producers to expand production. The incentive structure indicates that government through its macroeconomic and sect oral policies tend not to protect local producers and thus not enhancing output. There is a need for intensified effort and policy attention on sweet potato production if Nigeria is going to attain selfsufficiency in the production of sweet potato and compete in the market with other countries.

\section{REFERENCES}

ADB (2013). Project performance audit report: Cape Rodney smallholder development project in Papua New Guinea. No. L656- PNG (SF), Asian Development Bank, Nigeria 
Adeoye I.B. and Oni O.A. (2013). Policy analysis and competitiveness of plantain processing in South Western Nigeria. J. Sustainable Dev. Africa, 15 (7), 135-151

Adubasim C.V., Law-Ogbomo K.E. and Obalum S.E. (2017). Sweet potato (Ipomoea batatas) growth and tuber yield as influenced by plant spacing on sandy loam in humid tropical environment. Agro-Science, $\mathbf{1 6}$ (3), 46-50. DOI: https://dx.doi.org/10.4314/as.v16i3.7

David S. (2015). Getting a piece of the pie: an analysis of factors influencing women's production of Sweetpotato in Northern Nigeria. J. Gender Agric. Food Security, 1(1), 1- 19

Ekunwe P.E. and Atalor V.I. (2007). Returns on investment in plantain processed products in Benin City, Nigeria. J. Food, Agric. Environ., 5 (1), 82-84

FAO (2001). Gender and Food Security. Food and Agriculture Organization (FAO) of United Nations, Rome. www.Worldbank.org

FAO (2013). Food and Agriculture Organization (FAO) of United Nations, Rome. Farm Management Extension Guide, pp.104

FAOSTAT (2017). Food and Agriculture Organization Statistical Data Base Result. Retrieved June 2018

Hill R. and Vigneri M. (2011). Mainstreaming gender sensitivity in cash crop market supply chains $J$. Gender, Agric. Food Security, 1 (1), 1-19

Kahan D. (2013) Market-oriented farming: an overview. Food and Agriculture Organization ( FAO) of the United Nations, Rome. 151 pp.

Latruffe L. (2010). Competitiveness, productivity and efficiency in the agricultural and agri-food sectors. OECD Food, Agriculture and Fisheries Papers, 30, OECD Publishing. http://dx.doi.org/10.1787/5km91nkdt6d6-en
Masters W. and Winter-Nelson A. (1995). Measuring the comparative advantage of agricultural activities: domestic resource costs and the social cost-benefit ratio. Am. J. Agric Econs., 77 (2), 243-350

Mazumdar D. (1987). Rural-urban migration in developing countries. Chapter 28 In: Mills E.S. (Ed.), Handbook of Regional and Urban Economics, 2, Amsterdam: Elsevier, pp. 1097-1128

Monke E.A. and Pearson S.R. (1989). The policy analysis matrix for agricultural development. Ithaca and London: Cornell University Press

Ogbe A.O. Okoruwa V.O. and Jelili O.S. (2011). Competitiveness of Nigerian rice and maize production ecologies: a policy analysis approach. Trop. Subtrop. Agroecosys., 14, 493-500

Pearson S., Gotsch C. and Bahri S. (2003). Applications of the policy analysis matrix in Indonesian agriculture. Development Alternative Inc. - Food Policy Support Activity (DAI-FPSA) Indonesia in Collaboration with Yayasan Obor, Indonesian Member of IKAPI-DKI, Jakarta, pp. 240-241

Quisumbing A. (2003). Agriculture and natural resources: overview. In: Quisumbing A. (Ed.) Household Decisions, Gender and Development: A Synthesis of Recent Research. Washington DC: International Food Policy Research Institute

Quisumbing A., Meinzen-Dick R., Terri R., Raney L., Compensated A., Behrman J.A. and Peterman A. (2014). Gender in agriculture: closing the knowledge gap. International Food Policy Research Institute, Washington DC

Timmer P. (2005). Agriculture and Pro-poor Growth: An Asian Perspective. Working Paper No. 63 (July 2005). Centre for Global Development 